NBER WORKING PAPER SERIES

THE DEMAND FOR ILLICIT DRUGS

Henry Saffer

Frank Chaloupka

Working Paper No. 5238

NATIONAL BUREAU OF ECONOMIC RESEARCH

1050 Massachusetts Avenue

Cambridge, MA 02138

August 1995

The authors would like to thank Michael Grossman, John DiNardo and Robert Ohsfeldt for helpful comments. We would also like to thank Esel Yazici and Ismail Sirtalan for programming assistance, Joseph Gfroerer and Janet Greenblatt for assistance in merging the state data to the National Household Survey of Drug Abuse and Carolyn Hoffman for the cocaine and heroin price data. This paper is part of NBER's research program in Health Economics. Any opinions expressed are those of the authors and not those of the National Bureau of Economic Research.

(C) 1995 by Henry Saffer and Frank Chaloupka. All rights reserved. Short sections of text, not to exceed two paragraphs, may be quoted without explicit permission provided that full credit, including $\odot$ notice, is given to the source. 


\title{
THE DEMAND FOR ILLICIT DRUGS
}

\begin{abstract}
The purpose of this paper is to estimate the effects of heroin prices, cocaine prices and marijuana decriminalization on the demand for these three drugs, respectively. There are few prior empirical studies in this area because data have been difficult to acquire. This paper makes use of newly available data on drug prices and is the first to link these data to a sample of 49,802 individuals from the National Household Survey of Drug Abuse. The new drug price data comes from the Drug Enforcement Agency. The results provide empirical evidence that drug use is more price responsive than has been previously thought. The results show that the participation price elasticity for heroin is about -.90 to -.80 and that the participation price elasticity for cocaine is about -.55 to -.36 . Marijuana decriminalization was also found to increase the probability of marijuana participation by about 4 to 6 percent. The price elasticity for heroin is estimated at about -1.80 to -1.60 and for cocaine at about -1.10 to -.72 . It is estimated that legalization would lead to about a 100 percent increase in the quantity of heroin consumed and about a 50 percent increase in the quantity of cocaine consumed.
\end{abstract}

Henry Saffer

National Bureau of Economic Research 269 Mercer Street

New York, NY 10003
Frank Chaloupka

Department of Economics (M/C 144) University of Illinois at Chicago

601 South Morgan

Chicago, IL 60607-7121 and NBER 


\section{Introduction}

Illicit drug use imposes significant costs on society and on the individual users. These costs include drug related crime, drug related health problems, and drug related employment problems. According to Goldstein (1985) drugs are related to crime in three ways. First, there is a psycho-pharmacological relationship, where use or withdrawal increases excitability or reduces nervousness associated with participation in violent crimes. Second, there is an economic relationship where users commit non-violent and violent crimes to finance their habits. Finally, there is a systemic relationship in which violence is a characteristic of the business environment. Drugs also impose external crime costs by degrading neighborhoods, creating environments where criminal activity inflicted on non-users can flourish. Health costs from illicit drug use can result from accidental overdoses or toxic reactions to other substances included in the drug mixture. Health costs also come from increased accidents, especially on the highway and at work. In addition there is the physical, social and emotional damage caused to children by drug abusing parents. Employment costs from illicit drug use are lost income due to reduced productivity, increased unemployment and absenteeism and changes in career choice. In the workplace, external costs include the cost to the firm of drug use related terminations, absenteeism and performance problems.

Because of these considerable costs, government, at all levels, have made drug control an important priority. The federal government has undertaken an aggressive program of interdiction of drug shipments and eradication of drug crops in the field. The federal government and the state governments have also increased their criminal justice efforts. According to the Office of National Drug Control Policy (1995) the 1996 government budget requests $\$ 9.3$ billion for 
interdiction, crop reduction, and criminal justice. Estimates of drug price elasticities would be useful in evaluating these federal efforts. There is, however, very little empirical research on drug price elasticities.

In analyzing the effect of government drug control programs economists have applied the conventional supply and demand model to illicit drug markets. The model includes a demand function which is downward sloping with respect to full price. This model also includes a supply function which is upward sloping or horizontal with respect to the full price. Drug programs like interdiction and drug sanctions are assumed to raise equilibrium price. The effect on equilibrium quantity is dependent on the elasticity of demand which is often assumed to be inelastic. If demand is inelastic and price is increased it would increase total revenue to drug suppliers. This might require an increase in property crime to finance drug use. However, since drug price elasticities are not known, this remains a speculative exercise.

The purpose of this paper is to estimate the effects of drug prices on drug use. There are few prior empirical studies in this area because data has been difficult to acquire. This paper makes use of newly available data on drug prices and is the first paper to link these data to a nationally representative drug use data set of 49,802 individuals. The new drug price data come from the Drug Enforcement Agency. The data set used in this study is the largest and most comprehensive data set on drug use and drug prices that has ever been used in an empirical study. Estimates of drug price elasticities are important empirical evidence that drug sales can be characterized by market forces. Drug price elasticities are also important in estimating the likely impact of policies that affect drug prices and in estimating the costs and benefits of drug prohibition. 


\section{Prior Studies}

There are a few prior empirical studies of the effect of drug prices on drug use or on related outcomes. ${ }^{1}$ A study by van Ours (1995) uses data on opium in Indonesia during the Dutch colonial period. He finds a price elasticity of -.7 to -1.0 for use and -.3 to -.4 for participation. DiNardo (1993) studies the effect of cocaine price on cocaine use by high school seniors. He uses a state aggregated version of the Monitoring the Future (MTF) data set with drug prices from the Drug Enforcement Agency. He finds no effect of price on cocaine use. A study by Silverman and Spruill (1977) uses a pooled cross-sectional time-series data set on 41 neighborhoods of Detroit from November 1970 through July 1973. They find a price elasticity for heroin use in Detroit of about .26. Silverman and Spruill (1977) also find that property crime rates are positively and significantly affected by the price of heroin while non-property crime rates are not. Brown and Silverman (1974) use a time series on various crime rates in New York City to look at the impact of heroin prices on crime rates. They find that reductions in the price of heroin lead to a fall in property crimes but that prices have no impact on other crimes. The results from the crime studies suggest an inelastic demand for heroin. Nisbit and Vakil (1972) use data collected from interviews with UCLA students to estimate the demand for marijuana. They estimate the price elasticity of marijuana at -.7 to -1.0 .

There are also a few prior studies of the effect of marijuana decriminalization on marijuana participation. Marijuana decriminalization is a law which reduces the penalties for possession of a

\footnotetext{
${ }^{1}$ Drug consumption data typically have a relatively large number of observations with a value of zero which causes an econometric problem. Because of this problem three different drug consumption concepts are commonly used. Since this can result in some confusion it is important to explicitly define these three consumption concepts. Let participation be defined as a dichotomous event of either using drugs or not using drugs. Let 'use given participation' be defined as a continuous measure of consumption but only for individuals who participate. Finally, let use be defined as a continuous measure of consumption for all individuals, regardless of participation. These three consumption measures result in three different elasticity concepts. There is a participation elasticity, a 'use given participation' elasticity, and a use elasticity. The latter elasticity is the sum of the first two elasticities. Manning, Duan and Rogers (1987) discuss the econometric issues involved
} 
small amount of marijuana. Marijuana decriminalization thus has the effect of reducing the full price of marijuana use. Pacula (1994) used the National Longitudinal Survey of Youth (NLSY) to study the relationship between marijuana and alcohol. She included a variable measuring decriminalization but found no effect on marijuana use. Thies and Register (1993) studied the effect of marijuana decriminalization on use. They also used the NLSY and also concluded that decriminalization had no effect on use. DiNardo and Lemieux (1992) studied the relationship between marijuana and alcohol. They used the MTF surveys and included a variable measuring marijuana decriminalization. They too found that decriminalization had no effect on marijuana participation. Johnston, O'Malley and Bachman (1981) studied the effect of marijuana decriminalization using the MTF surveys of high school seniors. They concluded that decriminalization had no effect on marijuana use. All of these studies are based on samples of young people whose behavior may not be representative of the overall population.

Model (1992) studied the effect of marijuana decriminalization on crime rates using state aggregate data from the Uniform Crime Reports. She finds that decriminalization had a significant positive effect on property crimes and a significant negative effect on violent crimes. Model (1993) also studied the effect of decriminalization on hospital emergency room drug episodes. She used data from the Drug Abuse Warning Network and found that decriminalization increases marijuana use.

\section{Data Set}

\subsection{National Household Survey on Drug Abuse (NHSDA)}

The empirical models estimated in this paper are demand curves. The basis of these empirical demand curves is the same theoretical demand model that is used for legal goods. 
Theoretical drug demand curves are derived in the usual fashion by maximizing individual utility subject to a budget constraint consisting of the full price of drugs, other prices and income. The derived demand curves show that drug consumption is negatively related to the full price and related, without a priori sign, to income and taste. The demand curves in this study are estimated with a pooled set of data from the 1988, 1990 and 1991 National Household Surveys on Drug Abuse. The pooled data set consists of 49,802 observations, which is important since the larger sample increases the number of drug users surveyed and the precision of the estimates. The NHSDA are cross-sectional surveys of the US household population aged 12 or older and contain information on socioeconomic characteristics as well as data on drug and alcohol use. These surveys exclude residents of non-institutional group quarters (i.e. college dormitories) and exclude residents of institutional group quarters (i.e. prisons). Also excluded are those people with no permanent residence (i.e. homeless and residents in transient hotels). Less than two percent of the population is excluded. The excluded two percent probably have a higher percentage of hard core drug users then the included 98 percent. These surveys are likely to be more representative of casual drug users rather than hard core drug users. As a nationally representative survey, the NHSDA has an important advantage over the NLSY and MTF surveys which are limited to youth. In addition to information on drug consumption, the surveys contain information on the gender, race, ethnicity, personal income, and marital status, for each individual surveyed. State level data on marijuana decriminalization and drug prices have been appended to the individual records based on state of residence. ${ }^{2}$

\footnotetext{
${ }^{2}$ We are indebted to the Office of Applied Studies, SAMHSA, for merging the state level data to the individual records in the NHSDA. With the exception of one PSU in 1990 and six PSUs in 1991, no locational identifiers are available due to confidentiality issues.
} 
The 1988, 1990 and 1991 surveys are very similar except for size. The 1991 survey is over three times as large as the 1988 and 1990 surveys. The 1991 survey is larger, in part, because six PSUs were oversampled. Each survey also oversamples persons aged 12-17, Hispanics and African Americans. A summary of the variable definitions and means are included in table 1. The means presented in this table are weighted so that they are comparable to a random sample of the US. ${ }^{3}$

\subsection{Dependent Variables}

The dependent variables in this study are dichotomous measures of heroin, cocaine and marijuana participation. These three drugs represent most of the illicit drug use in the US. ${ }^{4}$ Two dichotomous variables which measure participation were defined for each of the three drugs. The first participation variable is equal to one if the individual reports that they had used the substance during the past year and the second participation variable is for use in the past month. The number of individuals that report participation in the past year is about double the monthly participation for all three drugs. Annual participation may be interpreted as reflecting more occasional use while participation in the past month may be interpreted as more regular use.

\subsection{Drug Prices}

Prices for cocaine and heroin come from the

\footnotetext{
${ }^{3}$ The data are weighted using the analysis weight variable in each survey. The individual data is multiplied by the weight variable and then divided by the sum of the weight variable. The means for combined data are computed as a weighted average of weighted means for the three surveys. The weights are defined as the sample size divided by the total size of the three samples.

${ }^{4}$ There is some continuous quantity data but it does not use standard measurement units, i.e. bongs per day. There is also number of days used during the past 30 days. A number of trial regressions done with these number of days variables produced unstable and inconsistent results. For these reasons these data were not used.
} 
US Department of Justice, Drug Enforcement Agency's STRIDE data set. ${ }^{5}$ Drug Enforcement Administration agents and police narcotics officers purchase illicit drugs regularly. The price, purity, weight and other information are recorded in the STRIDE data set. One reason these price data are collected is so that DEA agents will know how much to offer when negotiating to buy from drug dealers. The price data are fairly accurate since inaccurate data would endanger these agents. The STRIDE data set provided by the DEA to the NBER contains cocaine and heroin data from 1977 through 1988 and 1991 for approximately 144 cities or towns. This data set has over 23,000 cocaine price observations and over 15,000 heroin price observations.

The procedure developed by Caulkins (1994) was followed with some modifications to estimate heroin and cocaine prices. Let $\mathrm{r}=$ purity, $\mathrm{w}=$ weight, $\mathrm{c}=$ city dummies, $\mathrm{t}=$ time dummies, and $p=$ price. First the $\log$ of purity was regressed on $\log$ of weight, city dummies and time dummies.

$$
\ln =\beta_{1} \ln w+\beta_{2} c+\beta_{3} t+\mu
$$

This regression was used to project an estimated purity variable for all observations. Next, the log of price was regressed on the log of the weight times the estimated purity, city dummies and time dummies. ${ }^{6}$ This regression was performed by entering $\log$ weight and $\log$ estimated purity as separate variables and constraining their coefficients to be identical.

$$
\ln p=\gamma_{1} \ln w+\gamma_{1} \ln r+\gamma_{2} c+\gamma_{3} t+\mu
$$

\footnotetext{
${ }^{3}$ There are price data for marijuana from the Drug Enforcement Agency's Domestic Cities Report. These prices are for retail and wholesale commercial grade marijuana for 19 cities in 16 states. Use of this data required a significant reduction in the number of observations used in the analysis. A number of alternative estimates of the price of marijuana were made with this data. The resulting price variables were inconsistent with all other price data in the data set and resulted in unstable coefficients when used in a series of alternative demand specifications. For these reasons, these marijuana price data were not used.

${ }^{6}$ This is a reduced form price equation from a supply and demand model. The city and time dummies are proxies for unobserved city and time specific factors.
} 
Setting weight at 1 unit and purity at 100 percent makes the $\log$ of these values zero. The estimated coefficients of the city dummies and time dummies were then used to predict a price for every city-time combination. The projected price is the price of one unit of 100 percent pure drug. The antilog was then computed and the local level prices were aggregated to the state level. This aggregation was computed as a weighted average of all the represented cites in the state. The population weights for each city were computed by dividing the city population by the total population of all represented cities in the state. The population data come from the City and County Databook (1993). Prices were adjusted to their real value in 1982-1984 dollars.

There are two issues regarding the price data that are important. The first issue is the exogeneity of price. If drug supply is upward sloping, then price and quantity would be endogenous. However, since the predicted price variable used in the regressions comes from a reduced form model it is uncorrelated with the error term in the demand equation. The second issue is measurement error. Merging individual level data with state level prices introduces a potential for measurement error due to matching. Any measurement error created by the matching problem is probably small since, in each state, most drug users are in the larger urban areas and, for each state, the drug price data comes mostly from the larger urban areas. If there is any matching measurement error in the price data, but it is uncorrelated with the included regressors, and the equation error term, then no bias will be introduced.

The full price of marijuana is, in part, reflected by the decriminalization law. This law specifically eliminates criminal sanctions for possession of small amounts of marijuana. Decriminalization of marijuana eliminates possible imprisonment for most first offense possession 
violations. Oregon, in 1973, was the first state to decriminalize marijuana. By 1978, 10 other states had followed, substantially reducing the penalties associated with marijuana possession. Decriminalization, by lowering the penalties associated with marijuana use, is expected to increase marijuana demand.

\subsection{Other Independent Variables}

Total personal income is defined as income from all sources including wages, selfemployment, social security, public assistance, child support and other pension income. Income is a continuous variable measured in dollars. If drugs are normal goods, increased income will lead to increased consumption. However, since health is a normal good, increased income may reduce the consumption of drugs. The net effect of an increase in income on drug demand is, thus, without a priori prediction. Sickles and Taubman (1991) find that income has a negative effect on illegal drug use among youth and young adults.

A group of dichotomous demographic variables have also been defined. These are age, race, gender and marital status. Four dummy age variables have been included to allow for differential age effects. These dummies are for ages 12-17, 18-20, 21-24 and 25-30, with over 30 the omitted age category. Age may have a negative effect on drug use if time costs or health costs of drug use increase with age. Sickles and Taubman (1991) find that age has a negative effect on illegal drug use. Drug use may also differ by race. A dichotomous variable equal to one if the individual reports that they are African American has been defined. A similar variable was defined for Hispanics. Sickles and Taubman (1991) find that, holding other things constant, African Americans and Hispanics are more likely to consume illegal drugs. However, DiNardo and Lemieux (1992) and Pacula (1994) find that minorities consume less or the same levels of 
illegal drugs as whites. Gender may also affect drug use. A dichotomous variable equal to one if the individual is male has been defined. Marital status may also affect drug use. A dichotomous variable equal to one if the individual is married has been defined. Since there are a number of missing values for this variable a second variable was defined. The second variable is defined as equal to one if the marital status data are missing and the missing data on marital status are recoded to zero. Theis and Register (1993) find that marriage has a negative effect on drug use.

Eight regional dummies are also included in a number of regressions. The regional dummies are based on the Census nine region division all of which are represented in the data set. There are only 33 states represented in all three years of the data set. These dummies account for regional specific influences uncontrolled by the included regressors.

\section{Regression Results}

Tables 2,3 and 4 present the estimation results for heroin, cocaine and marijuana participation, respectively. Probit techniques are use to estimate the participation models. ${ }^{7}$ Each of these three tables first presents a set of specifications which uses annual participation as the dependent variable followed by a set of specifications which uses monthly participation as the dependent variable. For heroin and cocaine, all specifications include price, income and time dummies. For marijuana, all specifications include decriminalization, income and time dummies. In addition to these variables, the first specification adds demographic variables, the second specification adds demographic variables and region dummies and the third specification adds only

\footnotetext{
${ }^{7}$ According to Maddala (1983) weighted regressions are not necessary since the sample design is based on exogenous variables.
} 
the region dummies. These alternatives are presented as a test of robustness with respect to specification. $^{8}$

The economic and legal variables are price, income and decriminalization. The price of heroin is negative and significant in five regressions and negative in one. The price of cocaine is negative and significant in three regressions and negative in the other three. The similarity of the heroin price coefficients and the cocaine price coefficients across specifications suggests that the results are not due to a simple coincidence of specification. Income is negative and significant in five heroin regressions indicating that the probability of heroin participation decreases with income. These results suggest that heroin is an inferior good. For cocaine and marijuana, income is mostly insignificant. Decriminalization is positive and significant in all regressions.

The demographic variables are gender, marital status, age and minority status. The results show that men use more of all drugs and married people less of all drugs. The age coefficients suggest a pattern of increasing then decreasing use with age. Marijuana is the more popular drug with the youngest people, cocaine with an older group and heroin with oldest group. For both heroin and cocaine, the African American variable is insignificant for annual participation but significant and positive for participation in the past month. For marijuana, the African American variable is negative and significant for annual participation regressions and insignificant for monthly participation. For heroin and cocaine, the Hispanic variable is negative and significant for annual participation. For marijuana, the Hispanic variable is negative and significant for all regressions. The results indicate that African Americans have higher probabilities of being regular

\footnotetext{
${ }^{8}$ Several state fixed effects models were also estimated. Since price is a non-linear function of the city dummies and time dummies price is strongly colinear with state dummies. The state fixed effects models resulted in insignificant price coefficients which is most likely due to the correlation between price and the state dummies.
} 
users of heroin, that both African Americans and Hispanics have higher probabilities of being regular users of cocaine and lower probabilities of marijuana use than the omitted race/ethnic categories.

Region and time dummies provide additional controls for omitted factors that affect drug use. For both heroin and cocaine, the regional dummies variables are insignificant. The time dummies are insignificant for heroin but negative and significant for cocaine. This suggests that, holding price and other factors in the regressions constant, cocaine use declined during the sample period. For marijuana, the region variables are generally significant indicating a good deal of regional variation in marijuana use. The time dummies are also generally significant and negative indicating a downward trend in marijuana use during the sample period.

\section{Discussion}

The regression results are used to estimate participation price elasticities for heroin and cocaine. ${ }^{9}$ These elasticities are reported in the last row of tables 2 and 3 . The three specifications are important as tests of robustness with respect to specification. However, the elasticities estimated from these three specifications fall over a wide range. Because of this variance in estimated elasticities it is important to look more closely at each specification. Two criteria are used to judge each specification. First, the price coefficient should be negative and significant. The critical t-value for a one tailed t-test, at five percent, is 1.64 . The second criteria is the significance of all the other included regressors. The region coefficients are almost entirely insignificant. The large number of coefficients that are individually insignificant affect

\footnotetext{
${ }^{9}$ Price elasticities are estimated by multiplying the normal density function of the estimated equation by the price variable coefficient and then by the ratio of the mean price to mean participation. The unweighted means were used in these computations rather than the weighted means which are reported in table 1 . The unweighted means were used since the estimated regression coefficients are based on unweighted data.
} 
computation of the elasticity by affecting the magnitude of the price coefficient and by affecting the magnitude of the density function evaluated at the means. These criteria, for both annual and monthly participation, and for both heroin and cocaine, suggest that the first specification is a superior specification for estimating price elasticities.

Using the first specification in tables 2 and 3, the elasticity of annual heroin participation is -.90 and monthly participation is -.80 . The elasticity of annual cocaine participation is -.55 and monthly participation is -.36 . Participation is more price elastic for annual use of both drugs. This is consistent with the assumption that annual participation measures occasional participation and monthly participation measures regular participation.

For commodities such as alcohol and cigarettes both participation and use elasticities are often estimated. Participation elasticities are based on dichotomous dependent variables while use elasticities require continuous quantity data. When data is available, use elasticities can be estimated in two steps. First, the participation elasticity is estimated. Second, using only non-zero values for the dependent variable, a use, given participation, elasticity is estimated. These two elasticities are added together. Prior studies of alcohol and cigarettes suggest that these two elasticities are about equal. The study by van Ours (1995) finds the use price elasticity of opium to be 2.5 times the participation elasticity. Assuming that the use price elasticity of heroin and cocaine are twice the participation elasticities, then the use price elasticities for heroin would be about -1.80 to -1.60 and for cocaine about -1.10 to -.66 . These computations show that drug sales are more price responsive than has been previously thought. ${ }^{10}$

\footnotetext{
${ }^{10}$ Rational addiction models cannot be estimated with the NHSDA since past and future drug participation is not measured in the data set. However, studies of alcohol and cigarette demand based on rational addiction models find long run price elasticities that are larger than those estimated by simpler models. Rational addiction drug demand models would probably generate even more price elastic estimates than reported in this paper.
} 
The effect of marijuana decriminalization was computed and the values are reported in the last row of table 4 . The effect was estimated by calculating the difference between the distribution function with all the coefficients and mean values and the distribution function with the decriminalization variable equal to zero. The effect of decriminalization is reported as a percentage. All of the marijuana specifications pass the criteria listed above for selecting specifications. The decriminalization variable is significant at the 1 percent level in all specifications, and the demographic and region dummies are all significant. Interestingly, there is very little variation in the estimated effect of decriminalization across specifications. The results show that decriminalization increases annual marijuana participation by about 6 to 7 percent and monthly participation by about 4 to 5 percent.

The results provide empirical evidence that drug use is price responsive. The price elasticities reported in this paper can be used to estimate the reduction in drug participation that is the result of the current drug prohibition. Ending drug prohibition would lead to large decreases in drug prices. A case can be made for assuming that legalization would lead to a 60 percent reduction in retail drug prices. Kleiman (1992) estimates that the illegal nature of drugs increases drug prices by about five times. Also, since alcohol and cigarettes are heavily taxed, drugs would undoubtedly also be heavily taxed. If legalization resulted in a 60 percent reduction in heroin and cocaine prices then there would be about a 54 percent increase in the number of occasional heroin users and about a 33 percent increase in the number of occasional cocaine users. This price decrease could also lead to about a 100 percent increase in the amount of heroin used and about a 50 percent increase in the amount of cocaine used. It is likely that the social costs of drug use would rise in similar proportions to the increase in use. 


\section{References}

Brown, G., and L.P. Silverman, "The Retail Price of Heroin: Estimation and Applications," in Quantitative Explorations in Drug Abuse Policy, I. Leveson editor, New York: Spectrum Publications, 1980.

Caulkins, J.P., Developing Price Series for Cocaine, Santa Monica CA: Rand, 1994.

Cragg, J., "Some Statistical Models for Limited Dependent Variables with Application to the Demand for Durable Goods", Econometrica, 39, 1971.

DiNardo, J. and T. Lemieux, "Alcohol, Marijuana, and American Youth: The Unintended Effects of Government Regulation", Working Paper No. 4212, National Bureau of Economic Research, 1992.

DiNardo, J. "Law Enforcement the Price of Cocaine and Cocaine Use", Mathematical and Computer Modeling, vol. 17, no. 2, 1993.

Goldstein, P.J., "The Drugs/Violence Nexus: A Tripartite Conceptual Framework," Journal of Drug Issues, 1985.

Goldstein, P.J., et al., "Crack and Homicide in New York City, 1988: A Conceptually Based Event Analysis", Contemporary Drug Problems, 1989.

Greene, W., Econometric Analysis, New York: Macmillan Publishing Company, 1990.

Johnston L., P. O'Malley, J. Bachman, Marijuana Decriminalization: The Impact on Youth 19751980, Ann Arbor, Michigan: Institute for Social Research, 1981.

Kleiman, M., Against Excess, New York: Basic Books, 1992.

Manning, W., N. Duan, and W. Rogers, "Monte Carlo Evidence on the Choice Between Sample Selection and Two-Part Models", Journal of Econometrics, 35, 1987.

Maddala, G.S., Limited Dependent and Qualitative Variables in Economics, Cambridge, England: Cambridge University Press, 1983.

Model, K., "Crime Violence and Drug Policy", unpublished paper, Harvard University, 1992.

Model, K., "The Effect of Marijuana Decriminalization on Hospital Emergency Room Drug Episodes: 1975-1978", Journal of the American Statistical Association, vol. 88, no. 423, 1993.

Nisbet, C. and F. Vakil, "Some Estimates of Price and Expenditure Elasticities of Demand for Marijuana Among UCLA Students", Review of Economics and Statistics, vol. 54, 1972. 
Office of National Drug Control Policy, National Drug Control Strategy Budget Summary, Washington, DC, 1995.

Pacula R., "Can Increasing the Beer Tax Reduce Marijuana Consumption?", unpublished paper, Duke University, Department of Economics, 1994.

Silverman, L.P., and N.L. Spruill, "Urban Crime and the Price of Heroin," Journal of Urban Economics, 1977.

Sickles, R. and P. Taubman, "Who Uses Illegal Drugs?" AEA Papers and Proceedings, vol. 81, no. 2, May 1991.

Thies, C., and C. Register, "Decriminalization of Marijuana and the Demand for Alcohol, Marijuana and Cocaine", The Social Science Journal, vol. 30, no. 4, 1993.

US Department of Commerce, Bureau of the Census, City and County Databook, Washington DC, US Government Printing Office, 1993.

van Ours, J., "The Price Elasticity of Hard Drugs: The Case of Opium in the Dutch East Indies, 1923-1938", Journal of Political Economics, vol. 103, no. 2., 1995. 
Table 1

Weighted Average Means from the Combined National Household Survey of Drug Abuse 1988, 1990, 1991*

\begin{tabular}{|l|l|}
\hline \multicolumn{1}{|c|}{ Variable } & \multicolumn{1}{c|}{ Definition and Mean } \\
\hline $\begin{array}{l}\text { Heroin } \\
\text { Participation }\end{array}$ & $\begin{array}{l}\text { Dichotomous indicator equal to one if a respondent reports using } \\
\text { heroin in the past year, } \mu=.0011 ; \text { and past month } \mu=.0004 .\end{array}$ \\
\hline $\begin{array}{l}\text { Cocaine } \\
\text { Participation }\end{array}$ & $\begin{array}{l}\text { Dichotomous indicator equal to one if a respondent reports using } \\
\text { cocaine in the past year, } \mu=.02 ; \text { and past month, } \mu=.0085 .\end{array}$ \\
\hline $\begin{array}{l}\text { Marijuana } \\
\text { Participation }\end{array}$ & $\begin{array}{l}\text { Dichotomous indicator equal to one if a respondent reports using } \\
\text { marijuana in the past year, } \mu=.071 ; \text { and past month, } \mu=.045 .\end{array}$ \\
\hline $\begin{array}{l}\text { Marijuana } \\
\text { Decriminalized }\end{array}$ & $\begin{array}{l}\text { A dichotomous indicator equal to one for states that have } \\
\text { eliminated incarceration as a penalty for most marijuana } \\
\text { possession offenses, } \mu=.303 .\end{array}$ \\
\hline Heroin Price & Price of one pure milligram of heroin in 1983 dollars, $\mu=\$ 8.36$. \\
\hline Cocaine Price & Price of one pure gram of cocaine in 1983 dollars, $\mu=\$ 111.47$. \\
\hline Real Income & Total personal income in 1983 dollars, $\mu=\$ 12,425$. \\
\hline Gender & A dichotomous variable equal to one for males, $\mu=.479$. \\
\hline Marital Status & $\begin{array}{l}\text { A dichotomous variable equal to one if married, } \mu=.569 . \text { A } \\
\text { dichotomous variable equal to one if marital status was missing is } \\
\text { also included, } \mu=.033 .\end{array}$ \\
\hline Age 12-17 & $\begin{array}{l}\text { A dichotomous variable equal to one if an individual is } 12 \text { to } 17 \\
\text { years of age, } \mu=.100 .\end{array}$ \\
\hline Age 18-20 & $\begin{array}{l}\text { A dichotomous variable equal to one if an individual is } 18 \text { to } 20 \\
\text { years of age, } \mu=.055 .\end{array}$ \\
\hline Age 21-24 & $\begin{array}{l}\text { A dichotomous variable equal to one if an individual is } 21 \text { to } 24 \\
\text { years of age, } \mu=.069 .\end{array}$ \\
\hline Age 25-30 & $\begin{array}{l}\text { A dichotomous variable equal to one if an individual is } 25 \text { to } 30 \\
\text { years of age, } \mu=.129 .\end{array}$ \\
\hline $\begin{array}{l}\text { African } \\
\text { American }\end{array}$ & $\begin{array}{l}\text { A dichotomous variable equal to one if an individual self-reports } \\
\text { that they are African American, } \mu=.116 .\end{array}$ \\
\hline Hispanic & $\begin{array}{l}\text { A dichotomous variable equal to one if an individual self-reports } \\
\text { that they are Hispanic, } \mu=.078 .\end{array}$ \\
\hline
\end{tabular}

* Final sample size when missing values were excluded is 49,802 . 
Table 2 Heroin Participation

\begin{tabular}{|c|c|c|c|c|c|c|}
\hline & \multicolumn{3}{|c|}{ Annual } & \multicolumn{3}{|c|}{ Monthly } \\
\hline Intercept & $\begin{array}{c}-2.355 \\
(14.08) \\
\end{array}$ & $\begin{array}{r}-2.234 \\
(8.70) \\
\end{array}$ & $\begin{array}{l}-2.318 \\
(9.79)\end{array}$ & $\begin{array}{c}-2.628 \\
(10.96) \\
\end{array}$ & $\begin{array}{l}-2.659 \\
(6.03) \\
\end{array}$ & $\begin{array}{l}-2.615 \\
(6.68) \\
\end{array}$ \\
\hline Heroin Price & $\begin{array}{r}-0.061 \\
(3.31) \\
\end{array}$ & $\begin{array}{l}-0.066 \\
(2.39) \\
\end{array}$ & $\begin{array}{l}-0.069 \\
(2.50)\end{array}$ & $\begin{array}{l}-0.069 \\
(2.45)\end{array}$ & $\begin{array}{l}-0.073 \\
(1.60)\end{array}$ & $\begin{array}{l}-0.084 \\
(1.93)\end{array}$ \\
\hline Income & $\begin{array}{c}-0.000011 \\
(2.62)\end{array}$ & $\begin{array}{c}-0.000012 \\
(2.62)\end{array}$ & $\begin{array}{c}-0.0000068 \\
(1.94)\end{array}$ & $\begin{array}{c}-0.000013 \\
(1.99)\end{array}$ & $\begin{array}{c}-0.000014 \\
(2.06)\end{array}$ & $\begin{array}{c}-0.0000069 \\
(1.36)\end{array}$ \\
\hline Gender & $\begin{array}{l}0.225 \\
(3.34) \\
\end{array}$ & $\begin{array}{l}0.229 \\
(3.38) \\
\end{array}$ & - & $\begin{array}{l}0.330 \\
(3.33) \\
\end{array}$ & $\begin{array}{l}0.340 \\
(3.35) \\
\end{array}$ & - \\
\hline Marital Status & $\begin{array}{l}-0.271 \\
(3.03)\end{array}$ & $\begin{array}{l}-0.273 \\
(3.02) \\
\end{array}$ & - & $\begin{array}{l}-0.262 \\
(2.09) \\
\end{array}$ & $\begin{array}{l}-0.263 \\
(2.06) \\
\end{array}$ & - \\
\hline Dummy for Marital Status & $\begin{array}{l}-0.249 \\
(1.70) \\
\end{array}$ & $\begin{array}{l}-0.247 \\
(1.67) \\
\end{array}$ & - & $\begin{array}{l}-0.576 \\
(1.95) \\
\end{array}$ & $\begin{array}{l}-0.608 \\
(1.96) \\
\end{array}$ & - \\
\hline Age 12-17 & $\begin{array}{l}-0.186 \\
(1.70)\end{array}$ & $\begin{array}{l}-0.192 \\
(1.73)\end{array}$ & - & $\begin{array}{l}-0.229 \\
(1.53)\end{array}$ & $\begin{array}{l}-0.238 \\
(1.55)\end{array}$ & - \\
\hline Age $18-20$ & $\begin{array}{l}-0.098 \\
(0.82) \\
\end{array}$ & $\begin{array}{l}-0.099 \\
(0.83) \\
\end{array}$ & - & $\begin{array}{l}-0.444 \\
(2.00) \\
\end{array}$ & $\begin{array}{l}-0.458 \\
(2.00) \\
\end{array}$ & - \\
\hline Age 21-24 & $\begin{array}{l}-0.139 \\
(1.16) \\
\end{array}$ & $\begin{array}{l}-0.135 \\
(1.12) \\
\end{array}$ & - & $\begin{array}{l}-0.030 \\
(0.21)\end{array}$ & $\begin{array}{l}-0.017 \\
(0.11) \\
\end{array}$ & - \\
\hline Age $25-30$ & $\begin{array}{l}0.021 \\
(0.22) \\
\end{array}$ & $\begin{array}{l}0.023 \\
(0.24) \\
\end{array}$ & - & $\begin{array}{l}-0.039 \\
(0.29)\end{array}$ & $\begin{array}{l}-0.018 \\
(0.14)\end{array}$ & - \\
\hline African American & $\begin{array}{c}0.040 \\
(0.53) \\
\end{array}$ & $\begin{array}{l}0.061 \\
(0.77) \\
\end{array}$ & - & $\begin{array}{l}0.273 \\
(2.55) \\
\end{array}$ & $\begin{array}{l}0.349 \\
(3.03) \\
\end{array}$ & - \\
\hline Hispanic & $\begin{array}{l}-0.125 \\
(1.45) \\
\end{array}$ & $\begin{array}{l}-0.116 \\
(1.31) \\
\end{array}$ & - & $\begin{array}{r}0.088 \\
(0.74) \\
\end{array}$ & $\begin{array}{l}0.103 \\
(0.84) \\
\end{array}$ & - \\
\hline Middle Atlantic & - & $\begin{array}{l}-0.150 \\
(0.79) \\
\end{array}$ & $\begin{array}{l}-0.159 \\
(0.87) \\
\end{array}$ & - & $\begin{array}{l}0.094 \\
(0.27) \\
\end{array}$ & \begin{tabular}{|c|}
0.158 \\
$(0.51)$ \\
\end{tabular} \\
\hline East North Central & - & $\begin{array}{l}-0.045 \\
(0.23) \\
\end{array}$ & $\begin{array}{l}-0.047 \\
(0.25) \\
\end{array}$ & - & $\begin{array}{l}-0.292 \\
(0.75) \\
\end{array}$ & $\begin{array}{l}-0.197 \\
(0.56) \\
\end{array}$ \\
\hline West North Central & - & $\begin{array}{l}-0.051 \\
(0.17) \\
\end{array}$ & $\begin{array}{l}-0.037 \\
(0.13) \\
\end{array}$ & - & $\begin{array}{c}0.547 \\
(1.34) \\
\end{array}$ & $\begin{array}{l}0.591 \\
(1.57) \\
\end{array}$ \\
\hline South Atlantic & - & $\begin{array}{l}-0.102 \\
(0.53) \\
\end{array}$ & $\begin{array}{l}-0.088 \\
(0.47) \\
\end{array}$ & - & $\begin{array}{l}-0.086 \\
(0.24)\end{array}$ & $\begin{array}{l}0.054 \\
(0.16)\end{array}$ \\
\hline East South Central & - & $\begin{array}{l}-4.206 \\
(0.001) \\
\end{array}$ & $\begin{array}{l}-4.126 \\
(0.001) \\
\end{array}$ & - & $\begin{array}{c}-4.041 \\
(0.00061) \\
\end{array}$ & $\begin{array}{c}-3.759 \\
(0.00054)\end{array}$ \\
\hline West South Central & - & $\begin{array}{l}-0.012 \\
(0.061) \\
\end{array}$ & $\begin{array}{l}-0.066 \\
(0.36) \\
\end{array}$ & - & $\begin{array}{l}0.081 \\
(0.23) \\
\end{array}$ & $\begin{array}{l}0.135 \\
(0.42) \\
\end{array}$ \\
\hline Mountain & - & $\begin{array}{l}0.103 \\
(0.54) \\
\end{array}$ & $\begin{array}{r}0.049 \\
(0.26) \\
\end{array}$ & - & $\begin{array}{l}0.379 \\
(1.10) \\
\end{array}$ & $\begin{array}{l}0.316 \\
(1.00)\end{array}$ \\
\hline Pacific & - & $\begin{array}{l}-0.219 \\
(1.13) \\
\end{array}$ & $\begin{array}{l}-0.281 \\
(1.50) \\
\end{array}$ & - & $\begin{array}{l}-0.111 \\
(0.31) \\
\end{array}$ & $\begin{array}{l}-0.107 \\
(0.33) \\
\end{array}$ \\
\hline 1990 & $\begin{array}{l}-0.082 \\
(0.71) \\
\end{array}$ & $\begin{array}{l}-0.078 \\
(0.65) \\
\end{array}$ & $\begin{array}{l}-0.033 \\
(0.28) \\
\end{array}$ & $\begin{array}{l}-0.263 \\
(1.53) \\
\end{array}$ & $\begin{array}{l}-0.250 \\
(1.39) \\
\end{array}$ & $\begin{array}{l}-0.194 \\
(1.11)\end{array}$ \\
\hline 1991 & $\begin{array}{l}-0.039 \\
(0.42) \\
\end{array}$ & $\begin{array}{l}-0.055 \\
(0.57) \\
\end{array}$ & $\begin{array}{l}-0.025 \\
(0.27) \\
\end{array}$ & $\begin{array}{l}-0.126 \\
(1.01) \\
\end{array}$ & $\begin{array}{l}-0.157 \\
(1.17) \\
\end{array}$ & $\begin{array}{l}-0.100 \\
(0.78) \\
\end{array}$ \\
\hline R-square & 0.060 & 0.069 & 0.047 & 0.086 & 0.115 & 0.060 \\
\hline Price Elasticity & -0.90 & -0.56 & -0.66 & -0.80 & -0.36 & -0.70 \\
\hline
\end{tabular}

Note: Absolute value of asymptotic $\mathbf{t}$-statistics is in parentheses. 
Table 3 Cocaine Participation

\begin{tabular}{|c|c|c|c|c|c|c|}
\hline & \multicolumn{3}{|c|}{ Annual } & \multicolumn{3}{|c|}{ Monthly } \\
\hline Intercept & $\begin{array}{l}-1.598 \\
(19.24)\end{array}$ & $\begin{array}{c}-1.676 \\
(12.70)\end{array}$ & $\begin{array}{c}-1.658 \\
(13.73)\end{array}$ & $\begin{array}{c}-2.036 \\
(18.49)\end{array}$ & $\begin{array}{l}-2.113 \\
(12.02)\end{array}$ & $\begin{array}{l}-2.012 \\
(12.67)\end{array}$ \\
\hline Cocaine Price & $\begin{array}{l}-0.0029 \\
(4.71) \\
\end{array}$ & $\begin{array}{c}-0.0016 \\
(1.67) \\
\end{array}$ & $\begin{array}{l}-0.0013 \\
(1.54) \\
\end{array}$ & $\begin{array}{c}-0.0018 \\
(2.21)\end{array}$ & $\begin{array}{c}-0.0006 \\
(0.49)\end{array}$ & $\begin{array}{c}-0.0014 \\
(1.22)\end{array}$ \\
\hline Income & $\begin{array}{c}0.000002 \\
(1.46) \\
\end{array}$ & $\begin{array}{c}0.0000017 \\
(1.22)\end{array}$ & $\begin{array}{c}0.0000044 \\
(4.20)\end{array}$ & $\begin{array}{c}-0.0000015 \\
(0.79)\end{array}$ & $\begin{array}{c}-0.0000019 \\
(0.99)\end{array}$ & $\begin{array}{c}0.0000015 \\
(1.06)\end{array}$ \\
\hline Gender & $\begin{array}{c}0.265 \\
(10.35) \\
\end{array}$ & $\begin{array}{c}0.266 \\
(10.36)\end{array}$ & - & $\begin{array}{l}0.275 \\
(8.15) \\
\end{array}$ & $\begin{array}{r}0.278 \\
(8.20) \\
\end{array}$ & - \\
\hline Marital Status & $\begin{array}{c}-0.421 \\
(13.10) \\
\end{array}$ & $\begin{array}{c}-0.420 \\
(13.00) \\
\end{array}$ & - & $\begin{array}{c}-0.447 \\
(10.27) \\
\end{array}$ & $\begin{array}{c}-0.445 \\
(10.16) \\
\end{array}$ & - \\
\hline Dummy for Marital Status & $\begin{array}{r}-0.696 \\
(8.17) \\
\end{array}$ & $\begin{array}{r}-0.699 \\
(8.20) \\
\end{array}$ & - & $\begin{array}{l}-0.806 \\
(5.76) \\
\end{array}$ & $\begin{array}{l}-0.817 \\
(5.79)\end{array}$ & - \\
\hline Age $12-17$ & $\begin{array}{l}-0.110 \\
(2.39) \\
\end{array}$ & $\begin{array}{l}-0.111 \\
(2.40) \\
\end{array}$ & - & $\begin{array}{l}-0.213 \\
(3.55) \\
\end{array}$ & $\begin{array}{l}-0.214 \\
(3.55) \\
\end{array}$ & - \\
\hline Age $18-20$ & $\begin{array}{l}0.198 \\
(4.35)\end{array}$ & $\begin{array}{l}0.198 \\
(4.33)\end{array}$ & - & $\begin{array}{l}0.043 \\
(0.72)\end{array}$ & $\begin{array}{l}0.044 \\
(0.73)\end{array}$ & - \\
\hline Age 21-24 & $\begin{array}{l}0.372 \\
(9.45) \\
\end{array}$ & $\begin{array}{l}0.374 \\
(9.49) \\
\end{array}$ & - & $\begin{array}{l}0.251 \\
(4.95) \\
\end{array}$ & $\begin{array}{c}0.256 \\
(5.03) \\
\end{array}$ & - \\
\hline Age $25-30$ & $\begin{array}{c}0.375 \\
(10.98) \\
\end{array}$ & $\begin{array}{c}0.376 \\
(10.99) \\
\end{array}$ & - & $\begin{array}{r}0.292 \\
(6.63) \\
\end{array}$ & $\begin{array}{l}0.295 \\
(6.67) \\
\end{array}$ & - \\
\hline African American & $\begin{array}{c}0.016 \\
(0.54) \\
\end{array}$ & $\begin{array}{l}0.041 \\
(1.33) \\
\end{array}$ & - & $\begin{array}{l}0.185 \\
(4.86) \\
\end{array}$ & $\begin{array}{l}0.202 \\
(5.13) \\
\end{array}$ & - \\
\hline Hispanic & $\begin{array}{l}-0.047 \\
(1.44) \\
\end{array}$ & $\begin{array}{l}-0.057 \\
(1.73) \\
\end{array}$ & - & $\begin{array}{l}0.120 \\
(2.88) \\
\end{array}$ & $\begin{array}{c}0.107 \\
(2.52) \\
\end{array}$ & - \\
\hline Middle Atlantic & - & $\begin{array}{l}-0.045 \\
(0.58) \\
\end{array}$ & $\begin{array}{l}-0.060 \\
(0.81) \\
\end{array}$ & - & $\begin{array}{r}-0.0013 \\
(0.012) \\
\end{array}$ & $\begin{array}{l}0.025 \\
(0.25) \\
\end{array}$ \\
\hline East North Central & - & $\begin{array}{l}-0.110 \\
(1.41) \\
\end{array}$ & $\begin{array}{l}-0.117 \\
(1.57) \\
\end{array}$ & - & $\begin{array}{l}-0.081 \\
(0.75) \\
\end{array}$ & $\begin{array}{l}-0.045 \\
(0.45) \\
\end{array}$ \\
\hline West North Central & - & $\begin{array}{l}-0.085 \\
(0.79) \\
\end{array}$ & $\begin{array}{l}-0.096 \\
(0.94) \\
\end{array}$ & - & $\begin{array}{l}-0.138 \\
(0.92) \\
\end{array}$ & $\begin{array}{l}-0.127 \\
(0.89) \\
\end{array}$ \\
\hline South Atlantic & - & $\begin{array}{l}-0.124 \\
(1.60) \\
\end{array}$ & $\begin{array}{l}-0.128 \\
(1.76) \\
\end{array}$ & - & $\begin{array}{l}-0.101 \\
(0.95) \\
\end{array}$ & $\begin{array}{l}-0.035 \\
(0.35) \\
\end{array}$ \\
\hline East South Central & - & $\begin{array}{l}-0.295 \\
(2.87) \\
\end{array}$ & $\begin{array}{l}-0.305 \\
(3.10) \\
\end{array}$ & - & $\begin{array}{l}-0.436 \\
(2.83) \\
\end{array}$ & $\begin{array}{l}-0.369 \\
(2.56) \\
\end{array}$ \\
\hline West South Central & - & $\begin{array}{l}-0.061 \\
(0.76) \\
\end{array}$ & $\begin{array}{l}-0.100 \\
(1.32) \\
\end{array}$ & - & $\begin{array}{l}-0.018 \\
(0.16) \\
\end{array}$ & $\begin{array}{l}0.011 \\
(0.11) \\
\end{array}$ \\
\hline Mountain & - & $\begin{array}{r}0.129 \\
(1.59) \\
\end{array}$ & $\begin{array}{r}0.073 \\
(0.95) \\
\end{array}$ & - & $\begin{array}{r}0.125 \\
(1.13) \\
\end{array}$ & $\begin{array}{l}0.104 \\
(0.99) \\
\end{array}$ \\
\hline Pacific & - & $\begin{array}{l}-0.031 \\
(0.39) \\
\end{array}$ & $\begin{array}{l}-0.065 \\
(0.85) \\
\end{array}$ & - & $\begin{array}{l}-0.054 \\
(0.49) \\
\end{array}$ & $\begin{array}{l}-0.056 \\
(0.54) \\
\end{array}$ \\
\hline 1990 & $\begin{array}{l}-0.136 \\
(3.40) \\
\end{array}$ & $\begin{array}{l}-0.131 \\
(3.24) \\
\end{array}$ & $\begin{array}{l}-0.039 \\
(1.01) \\
\end{array}$ & $\begin{array}{r}-0.163 \\
(3.02) \\
\end{array}$ & $\begin{array}{l}-0.161 \\
(2.95) \\
\end{array}$ & $\begin{array}{l}-0.074 \\
(1.41) \\
\end{array}$ \\
\hline 1991 & $\begin{array}{l}-0.228 \\
(6.89) \\
\end{array}$ & $\begin{array}{l}-0.227 \\
(6.60) \\
\end{array}$ & $\begin{array}{l}-0.145 \\
(4.46) \\
\end{array}$ & $\begin{array}{l}-0.178 \\
(4.09) \\
\end{array}$ & $\begin{array}{l}-0.178 \\
(3.95) \\
\end{array}$ & $\begin{array}{l}-0.103 \\
(2.42) \\
\end{array}$ \\
\hline R - square & 0.080 & 0.083 & 0.020 & 0.085 & 0.089 & 0.023 \\
\hline Price Elasticity & -0.55 & -0.30 & -0.33 & -0.36 & -0.12 & -0.38 \\
\hline
\end{tabular}

Note: Absolute value of asymptotic t-statistics is in parentheses. 
Table 4 Marijuana Participation

\begin{tabular}{|c|c|c|c|c|c|c|}
\hline & \multicolumn{3}{|c|}{ Annual } & \multicolumn{3}{|c|}{ Monthly } \\
\hline Intercept & $\begin{array}{l}-1.500 \\
(46.70) \\
\end{array}$ & $\begin{array}{l}-1.281 \\
(24.19) \\
\end{array}$ & $\begin{array}{l}-1.042 \\
(22.81) \\
\end{array}$ & $\begin{array}{l}-1.672 \\
(46.09) \\
\end{array}$ & $\begin{array}{l}-1.501 \\
(24.60)\end{array}$ & $\begin{array}{l}-1.341 \\
(25.43) \\
\end{array}$ \\
\hline Decriminalized & $\begin{array}{l}0.151 \\
(8.76) \\
\end{array}$ & $\begin{array}{l}0.098 \\
(4.14) \\
\end{array}$ & $\begin{array}{r}0.093 \\
(4.10) \\
\end{array}$ & $\begin{array}{l}0.157 \\
(7.98)\end{array}$ & $\begin{array}{l}0.111 \\
(4.07) \\
\end{array}$ & $\begin{array}{l}0.113 \\
(4.32) \\
\end{array}$ \\
\hline Income & $\begin{array}{c}0.0000022 \\
(2.33)\end{array}$ & $\begin{array}{c}0.0000022 \\
(2.30)\end{array}$ & $\begin{array}{c}-0.00000003 \\
(0.045)\end{array}$ & $\begin{array}{c}-0.0000003 \\
(0.28)\end{array}$ & $\begin{array}{c}-0.0000003 \\
(0.27) \\
\end{array}$ & $\begin{array}{c}0.00000049 \\
(0.57)\end{array}$ \\
\hline Gender & $\begin{array}{c}0.272 \\
(16.04) \\
\end{array}$ & $\begin{array}{c}0.273 \\
(16.04) \\
\end{array}$ & - & $\begin{array}{c}0.296 \\
(15.16) \\
\end{array}$ & $\begin{array}{c}0.296 \\
(15.17) \\
\end{array}$ & - \\
\hline Marital Status & $\begin{array}{l}-0.422 \\
(19.23) \\
\end{array}$ & $\begin{array}{c}-0.418 \\
(18.98)\end{array}$ & - & $\begin{array}{l}-0.408 \\
(16.29) \\
\end{array}$ & $\begin{array}{l}-0.405 \\
(16.11)\end{array}$ & $\cdot$ \\
\hline Dummy for Marital Status & $\begin{array}{l}-0.667 \\
(17.09) \\
\end{array}$ & $\begin{array}{l}-0.669 \\
(17.09) \\
\end{array}$ & - & $\begin{array}{c}-0.691 \\
(13.66) \\
\end{array}$ & $\begin{array}{l}-0.694 \\
(13.68) \\
\end{array}$ & - \\
\hline Age $12-17$ & $\begin{array}{l}0.276 \\
(9.25) \\
\end{array}$ & $\begin{array}{l}0.280 \\
(9.34) \\
\end{array}$ & - & $\begin{array}{l}0.098 \\
(2.86) \\
\end{array}$ & $\begin{array}{l}0.101 \\
(2.94)\end{array}$ & - \\
\hline Age 18-20 & $\begin{array}{c}0.597 \\
(19.55) \\
\end{array}$ & $\begin{array}{c}0.601 \\
(19.63) \\
\end{array}$ & - & $\begin{array}{c}0.443 \\
(12.86) \\
\end{array}$ & $\begin{array}{c}0.447 \\
(12.93) \\
\end{array}$ & - \\
\hline Age 21-24 & $\begin{array}{c}0.578 \\
(20.72) \\
\end{array}$ & $\begin{array}{c}0.585 \\
(20.90) \\
\end{array}$ & - & $\begin{array}{c}0.464 \\
(14.77) \\
\end{array}$ & $\begin{array}{c}0.470 \\
(14.91)\end{array}$ & - \\
\hline Age $25-30$ & $\begin{array}{c}0.492 \\
(20.19) \\
\end{array}$ & $\begin{array}{c}0.494 \\
(20.23) \\
\end{array}$ & - & $\begin{array}{c}0.444 \\
(16.28) \\
\end{array}$ & $\begin{array}{c}0.447 \\
(16.32)\end{array}$ & - \\
\hline African American & $\begin{array}{l}-0.111 \\
(5.46) \\
\end{array}$ & $\begin{array}{l}-0.076 \\
(3.67) \\
\end{array}$ & - & $\begin{array}{l}0.010 \\
(0.46) \\
\end{array}$ & $\begin{array}{l}0.041 \\
(1.76) \\
\end{array}$ & - \\
\hline Hispanic & $\begin{array}{l}-0.273 \\
(12.51) \\
\end{array}$ & $\begin{array}{l}-0.277 \\
(12.17) \\
\end{array}$ & - & $\begin{array}{l}-0.219 \\
(8.68) \\
\end{array}$ & $\begin{array}{r}-0.223 \\
(8.51) \\
\end{array}$ & - \\
\hline Middle Atlantic & - & $\begin{array}{l}-0.260 \\
(5.00) \\
\end{array}$ & $\begin{array}{l}-0.334 \\
(6.79) \\
\end{array}$ & - & $\begin{array}{l}-0.187 \\
(3.12) \\
\end{array}$ & $\begin{array}{l}-0.240 \\
(4.22) \\
\end{array}$ \\
\hline East North Central & - & $\begin{array}{l}-0.161 \\
(3.24) \\
\end{array}$ & $\begin{array}{l}-0.201 \\
(4.27) \\
\end{array}$ & - & $\begin{array}{l}-0.130 \\
(2.25) \\
\end{array}$ & $\begin{array}{l}-0.151 \\
(2.76) \\
\end{array}$ \\
\hline West North Central & - & $\begin{array}{l}-0.239 \\
(3.74) \\
\end{array}$ & $\begin{array}{l}-0.247 \\
(4.04) \\
\end{array}$ & - & $\begin{array}{l}-0.217 \\
(2.89) \\
\end{array}$ & $\begin{array}{l}-0.240 \\
(3.34)\end{array}$ \\
\hline South Atlantic & - & $\begin{array}{l}-0.313 \\
(6.45) \\
\end{array}$ & $\begin{array}{l}-0.354 \\
(7.73) \\
\end{array}$ & - & $\begin{array}{l}-0.251 \\
(4.45) \\
\end{array}$ & $\begin{array}{l}-0.263 \\
(4.96) \\
\end{array}$ \\
\hline East South Central & - & $\begin{array}{l}-0.353 \\
(5.82) \\
\end{array}$ & $\begin{array}{l}-0.367 \\
(6.37) \\
\end{array}$ & - & $\begin{array}{l}-0.266 \\
(3.80) \\
\end{array}$ & $\begin{array}{l}-0.261 \\
(3.94) \\
\end{array}$ \\
\hline West South Central & - & $\begin{array}{l}-0.254 \\
(4.87) \\
\end{array}$ & $\begin{array}{l}-0.360 \\
(7.33) \\
\end{array}$ & - & $\begin{array}{l}-0.190 \\
(3.14) \\
\end{array}$ & $\begin{array}{l}-0.267 \\
(4.70) \\
\end{array}$ \\
\hline Mountain & - & $\begin{array}{l}-0.048 \\
(0.89) \\
\end{array}$ & $\begin{array}{r}-0.155 \\
(3.01) \\
\end{array}$ & - & $\begin{array}{l}0.014 \\
(0.23) \\
\end{array}$ & $\begin{array}{c}-0.091 \\
(1.54) \\
\end{array}$ \\
\hline Pacific & - & $\begin{array}{c}-0.164 \\
(3.08) \\
\end{array}$ & $\begin{array}{r}-0.280 \\
(5.58) \\
\end{array}$ & - & $\begin{array}{r}-0.136 \\
(2.21) \\
\end{array}$ & $\begin{array}{l}-0.236 \\
(4.06) \\
\end{array}$ \\
\hline 1990 & $\begin{array}{c}-0.143 \\
(5.12) \\
\end{array}$ & $\begin{array}{c}-0.126 \\
(4.48) \\
\end{array}$ & $\begin{array}{r}-0.022 \\
(0.83) \\
\end{array}$ & $\begin{array}{c}-0.164 \\
(5.17) \\
\end{array}$ & $\begin{array}{r}-0.150 \\
(4.68) \\
\end{array}$ & $\begin{array}{l}-0.046 \\
(1.52)\end{array}$ \\
\hline 1991 & $\begin{array}{r}-0.119 \\
(5.32) \\
\end{array}$ & $\begin{array}{r}-0.115 \\
(5.06) \\
\end{array}$ & $\begin{array}{l}-0.054 \\
(2.50) \\
\end{array}$ & $\begin{array}{l}-0.157 \\
(6.18) \\
\end{array}$ & $\begin{array}{r}-0.158 \\
(6.10)\end{array}$ & $\begin{array}{l}-0.080 \\
(3.29) \\
\end{array}$ \\
\hline$R$ - square & 0.092 & 0.095 & 0.017 & 0.087 & 0.090 & 0.017 \\
\hline Effect of Decriminalization & 0.0585 & 0.0596 & 0.0687 & 0.0411 & 0.0418 & 0.0499 \\
\hline
\end{tabular}

Note: Absolute value of asymptotic t-statistics is in parentheses. 